\title{
Are there Differences in Reflective Thinking Between Male and Female Prospective Mathematics Teachers?
}

\author{
Cholis Sa'dijah ${ }^{1, *}$ Muhammad N. Kholid ${ }^{1,2}$ Erry Hidayanto ${ }^{1}$ Hendro Permadi ${ }^{1}$
}

\author{
${ }^{1}$ Universitas Negeri Malang, Indonesia \\ ${ }^{2}$ Universitas Muhammadiyah Surakarta, Indonesia \\ ${ }^{*}$ Corresponding author. Email: cholis.sadijah.fmipa@um.ac.id
}

\begin{abstract}
Reflective thinking is a thinking process involves re-investigations to overcome confusion for problem solving. This type of thinking is important for prospective mathematics teachers because the thinking can be a competence for them to teach mathematics effectively. In Indonesia, in the last three years there have been more female prospective mathematics teachers than male. Geometry is one of the difficult topics for the prospective teachers. There are four aspects of reflective thinking, namely techniques, monitoring, insight, and conceptualization. This study examines the differences in reflective thinking of male and female prospective mathematics teachers in solving analytical geometry problems in the four aspects. This research approach is qualitative. The research instrument was developed by the researchers and already valid. This research conducted at the Universitas Negeri Malang and Universitas Muhammadiyah Surakarta. The amount of the subjects were 83 prospective mathematics teachers who have taken analytical geometry courses in 2019/2020. Researchers collected data through test and interview techniques. The instrument validation and triangulation processes are carried out as an effort to validate the data. Data analysed through the stages of reduction, presentation, and verification. The results of this study indicate that the differences in reflective thinking of both lies in the three aspects.
\end{abstract}

Keywords: Reflective thinking, prospective mathematics teachers, analytical geometry, problem solving.

\section{INTRODUCTION}

The development of mathematics has many roles for the discovery of other sciences [1]. Mathematics is an abstract patterned science to solve problems as a guide in studying other sciences and technology [2]. The problem solvers' ability to solve mathematical problems does not match the demands of solving new problems. Discrepancy is that problem solvers are not able to relate new problems with the knowledge and experience they have [3]. In solving a problem, they must employee a thinking process. Thinking as a mental activity that aims to make decisions or draw conclusions [4,5]. Furthermore, to obtain new knowledge, problem solvers need to employee attributes in thinking such as abstraction, logic, imagination, and problem solving [6]. Moreover, thinking is considered as a process of understanding in solving problems [7].

Prior studies say that there are differences in thinking skills in problem solving between male and female problem solvers. First, male problem solvers show better performance in solving problems employee spatial skills [8]. It is relevant to a statement that male problem solvers have a better strategy in solving mathematical problems in terms of insight [9]. Third, statistically men are able to solve mathematical problems better than women in terms of attitude [10]. The attitude mentioned is openmindedness. To sum up, the studies revealed that there are differences in thinking skills between male and female problem solvers. Unfortunately, there are no studies that focus on comparing reflective thinking skills between male and female problem solvers.

Reflective thinking as an active, persistent, and thoughtful thinking activity based on own knowledge in making decision [11]. Reflective thinking begins with confusion and re-evaluation for problem solving [12]. Reflective thinking is important for prospective mathematics teachers, it can be a competence for them to teach mathematics effectively. The authors have reviewed several studies related to reflective thinking. In general, these studies are grouped into three focuses. First, studies that produce instruments related to reflective thinking 
[13-17]. The instruments developed include: 1) the scale of reflective thinking, 2) the reflective thinking questionnaire, 3) the guidelines table for checking reflective thinking, and 4) the rubric for evaluating reflective thinking (REPORT). Second, research on the role of reflective thinking on problem solvers' performances [15], [18-23]. The results concluded that reflective thinking: 1) minimizes problem solvers' weaknesses in overcoming difficulties, 2) encourages problem solvers to obtain logical solutions, and 3) encourages problem solvers to re-evaluate the strategies used. Third, research that results in: 1) the category of reflective thinking [24], 2) the level of reflective thinking [15], and 3) aspects of reflective thinking [25].

Based on these studies reviewed, there is an opportunity to conduct research related to differences in reflective thinking between male and female prospective mathematics teachers. In Indonesia, in the last three years there have been more female prospective mathematics teachers than male. Data from Indonesian Ministry of Education shows that over the last three years the percentage of female teachers is around 66\%. Data presented in Figure 1.

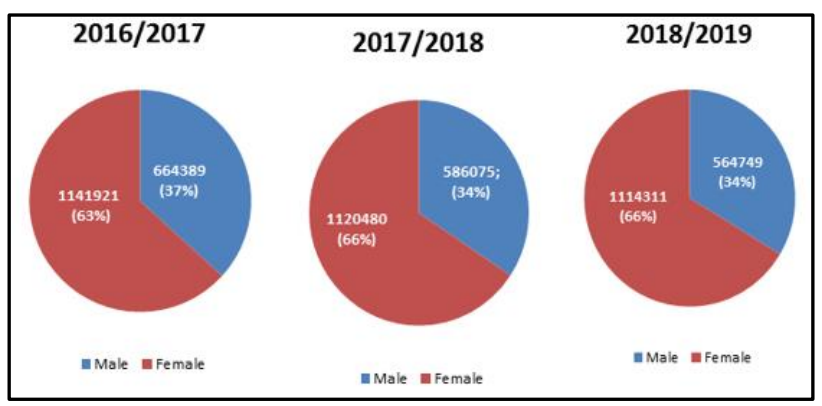

Figure 1 Percentage of teachers in Indonesia in terms of gender.

Reflective thinking begins with confusion by the problem solvers [26]. Thus, the type of question employed to understand problem solvers' reflective thinking is a question that can stimulate confusion. It may be a nonroutine problem-solving question. A non-routine problem-solving question is an unfamiliar problem for prospective mathematics teachers so it causes a confusion to stimulate the emergence of reflective thinking[3,27]. The type of question can be encountered in analytical geometry content. Furthermore, in solving analytical geometry problem they need to have a good understanding $[28,29]$. A non-routine question in analytical geometry content is an unfamiliar problem so that it can stimulate confusion. Moreover, a non-routine problem-solving question employee knowledge and experience. Thus, it is very compatible for understanding problem solvers' reflective thinking.

There are four components of reflective thinking [30], namely: (1) techniques, (2) monitoring, (3) insight (ingenuity), and (4) conceptualization. Authors conducted preliminary research to explore the indicators of each aspect. The indicators employed for this study presented in Table 1.

Table 1. Indicator of reflective thinking

\begin{tabular}{|c|c|}
\hline Aspects & Indicators \\
\hline Techniques & $\begin{array}{l}\text { 1. Finding how to understand the } \\
\text { information } \\
\text { 2. Finding how to understand the } \\
\text { question } \\
\text { 3. Selecting an effective and efficient } \\
\text { solution }\end{array}$ \\
\hline Monitoring & $\begin{array}{l}\text { 1. Monitoring the steps of solution } \\
\text { 2. Monitoring the answer whether } \\
\text { correct or not }\end{array}$ \\
\hline Insight & $\begin{array}{l}\text { 1. Being ready to correct wrong } \\
\text { answers } \\
\text { 2. Understanding how to avoid } \\
\text { difficulties }\end{array}$ \\
\hline Conceptualization & $\begin{array}{l}\text { 1. Thinking about an alternative } \\
\text { solution } \\
\text { 2. Relating concepts to question }\end{array}$ \\
\hline
\end{tabular}

The research aims to describe the differences in reflective thinking between male and female prospective mathematics teachers based on components of techniques, monitoring, insight, and conceptualization in solving a non-routine analytical geometry problem. The objective will be described qualitatively.

\section{METHODS}

\subsection{Design}

The research describes the differences in reflective thinking between male and female prospective mathematics. Data described the fact of prospective mathematics teachers' reflective thinking without any manipulation, it means the study employees a descriptive design [31].

\subsection{Participants}

The subjects were prospective mathematics teachers from Universitas Muhammadiyah Surakarta and Malang State University, totalling 83 participants (23 male and 60 female). The sampling employed is purposive method [32]. Subjects are prospective mathematics teachers taken analytical geometry courses, employee reflective thinking in solving problems, and have good communication skills. In this paper, data presented on two male subjects and two female subjects because their data represent the entire data. 


\subsection{Instruments}

The instruments employed in this study are: 1) test, 2) observation sheet, and 3) interview guidelines. The test contains an item of non-routine question. The question facilitates in measuring reflective thinking indicators. Moreover, observation sheet is a piece of sheet to check whether reflective thinking indicator satisfied or not. Researchers put a checklist sign $(\sqrt{ })$ in column "YES" if the subjects satisfy the indicator, in column "NOT" if the subjects do not satisfy the indicator, and in column "GREY" if the researchers feeling doubt whether the subjects satisfy the indicator or not. The doubt will be confirmed by in-depth interview. The focus of questions in in-depth interviews is to explore the subject's reflective thinking in solving problems more deeply. Besides that, in-depth interviews conducted to confirm whether the indicators of reflective thinking were carried out by the subject or not. The instruments declared as valid instruments by validators expert in mathematics, mathematics education, and thinking skill research.

\subsection{Data Collection Method}

Data collection techniques in this study are test, video recordings, interviews, and observation sheet. The test employed to understand prospective mathematics teachers' reflective thinking. Think aloud technique is the most effective method employed in solving problems to understand problem solvers' reflective thinking [33]. The problem presented in Figure 2.

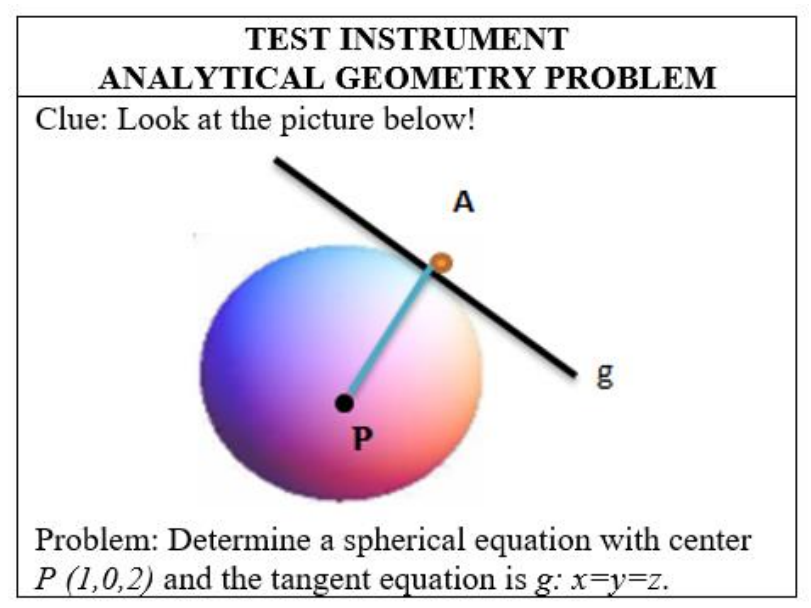

Figure 2 The non-routine problem-solving question in analytical geometry content.

\subsection{Data Analysis}

Data analysis through the stage of data reduction, data presentation, and drawing conclusions. In reduction stage, data reduced by referring to the aim of the research. In presentation stage, the data of subjects' reflective thinking reported. The data triangulation process conducted by matching the subject's reflective thinking data obtained by the test method, video recordings, interviews, and observation sheets. The data employed at triangulation process are only data that support researchers to draw conclusions. The complete research procedure presented in Figure 3

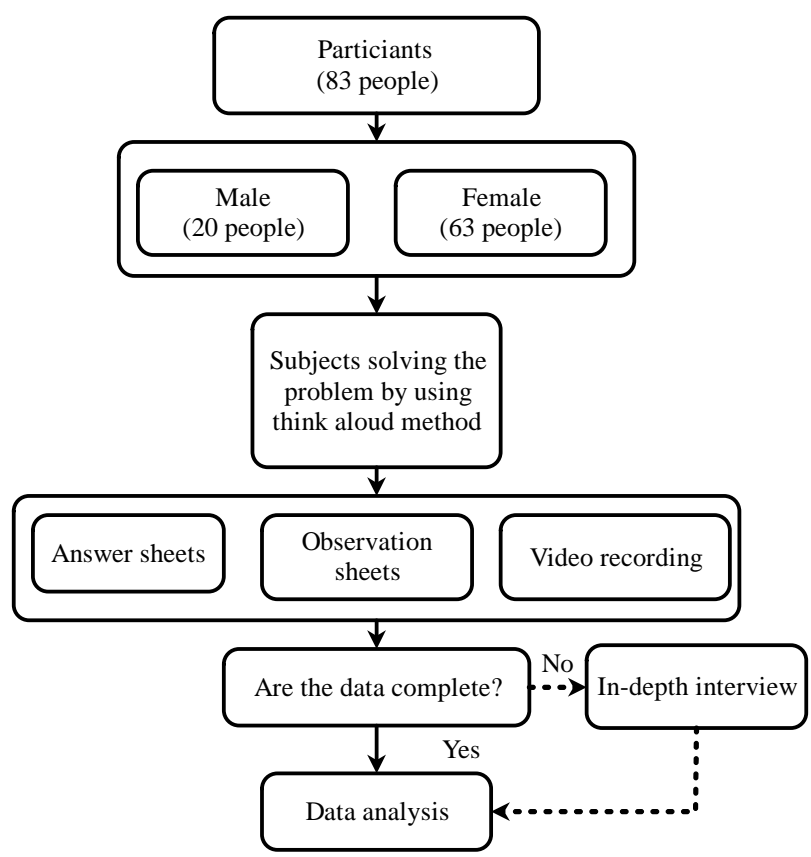

Figure 3 Research Procedure.

\section{FINDING}

In this section data are presented from two male subjects (S-1 and S-2) and two female subjects (S-3 and S-4).

\subsection{Subject $S$-1: data exposure and analysis}

Figure 4 depicts the answer sheet of S-1. S-1 rewrote the given information. The direction number of line $g: x=$ $y=z$ written as $1,1,1$. S- 1 determined the equation of plane $V$ where $V$ throughs point $P(1,0,2)$ and perpendicular to line $g$. After obtaining the equation $V: x+y+z-3=0$, S-1 thought of a way to determine the intersection between plane $V$ and line $g$. At this stage, S-1 employed the parameter $t$. The intersection should be $A(1,1,1)$. Thus, the radius is the distance between $P$ and $A$, which is $r=\sqrt{2}$. S -1 understood that the spherical has $P(1,0,2)$ and radius $r=\sqrt{2}$. S-1 determined equation of the spherical is $x^{2}+y^{2}+z^{2}-2 x-4 z+3=0$. In determining the spherical equation, $\mathrm{S}-1$ experienced confusion, this seems to be a graffiti on the answer sheet. S-1 overcome confusion by checking the completion steps and answers. 

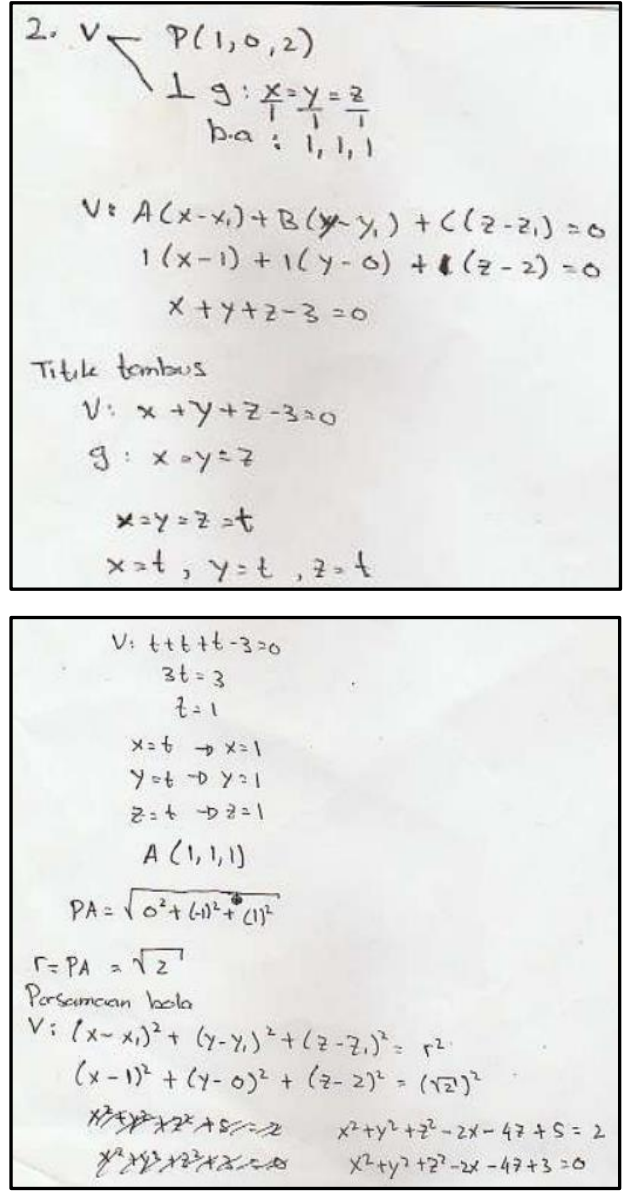

Figure 4 Answer sheet of S-1.

\subsection{Subject $S$-2: data exposure and analysis}

Figure 5 is the answer sheet of S-2. S-2 rewrote the given information. S-2 understands that the directional number of line $g: 1,1,1$. First, $\mathrm{S}-2$ determined the equation of plane $V$, where $V$ throughs point $P(1,0,2)$ and perpendicular to line $g$. At this stage the $\mathrm{S}-2$ experiences confusion. He made a mistake in substituting the directional numbers into the plane equation. S-2 overcome confusion by clarifying. It means checking back the direction numbers. He determined equation of $V: x+y+z$ $3=0$. Next, he determined the intersection between plane $V: x+y+z-3=0$ and the line $g: x=y=z$. In this step, S-1 experienced confusion, this seems to be a graffiti on the answer sheet. The parameter $t$ employed to determine the intersection $A$. After conducting a calculation, he got the intersection is $A(1,1,1)$.
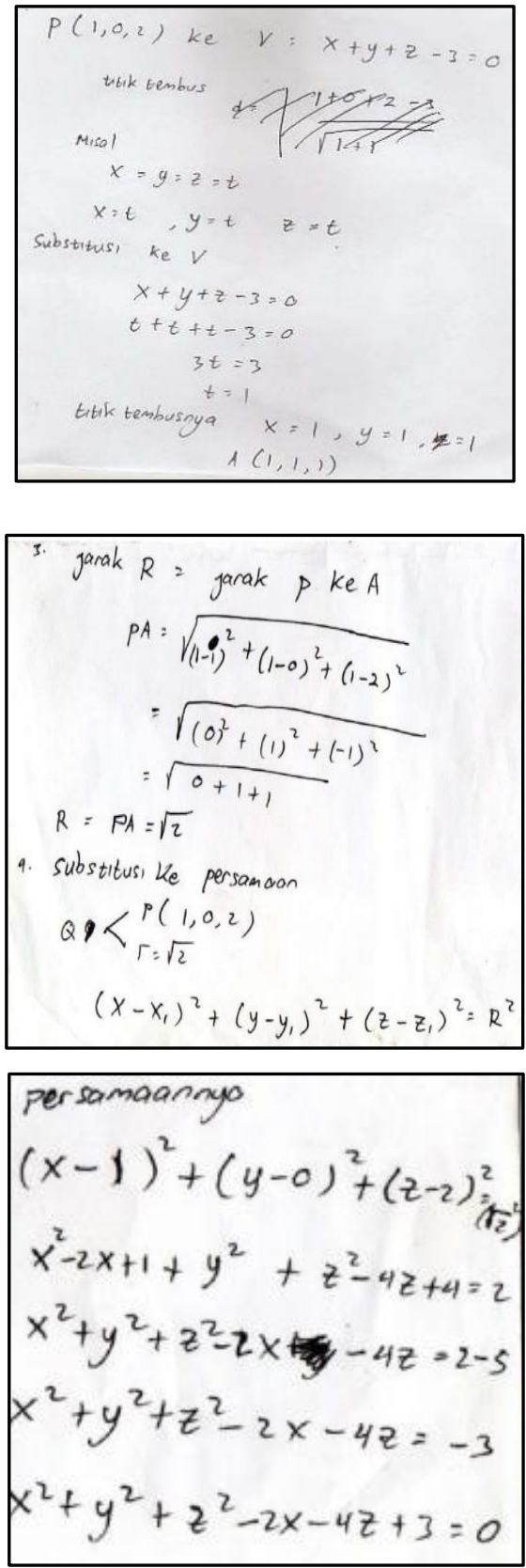

Figure 5 Answer sheet of S-2.

\subsection{Subject S-3: data exposure and analysis}

Figure 6 illustrated the answer sheet of S-3. She did not re-write the given information. However, she drew back the given sketches to facilitate solving problem. First, S-3 determines the radius of the spherical. After conducting calculation, she gets $r=\sqrt{3 x_{1}^{2}-6 x_{1}+5}$. In determining value $r, \mathrm{~S}-3$ experienced confusion, this seems to be a graffiti on the answer sheet. Re-monitoring conducted to overcome the confusion. She understood that the spherical equation is $\left(x-x_{1}\right)^{2}+\left(y-y_{1}\right)^{2}+(z-$ $\left.z_{1}\right)^{2}=r^{2}$. However, S-3 cannot do conceptualization that causes errors in drawing conclusions. She concluded that there is no sphere under centre $P(1,0,2)$ and tangents $g: x=y=z$. 

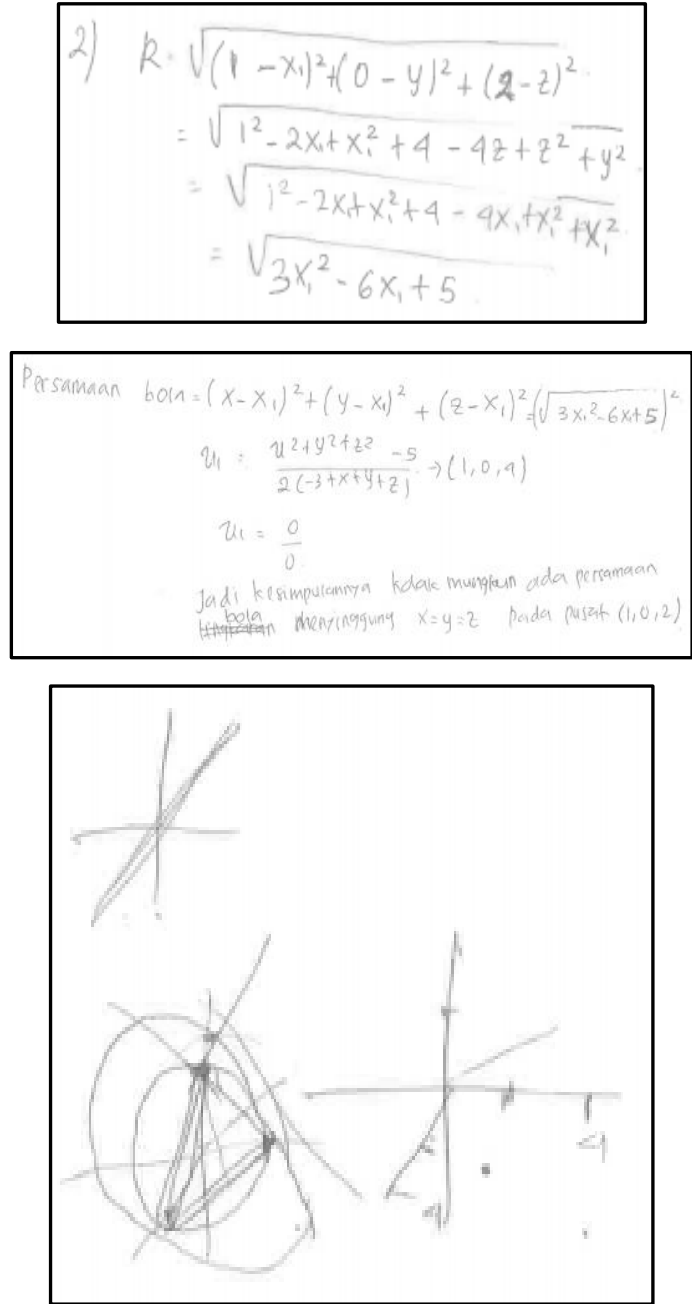

Figure 6 Answer sheet of S-3.

\subsection{Subject $S$-4: data exposure and analysis}

Fig 7 depicts the S-4 answer sheet. In solving analytical geometry problems, she does not rewrite the given information. S-4 understands that the sphere equation $(x-a)^{2}+(y-b)^{2}+(z-c)^{2}=r^{2}$ with the center $(a, b, c)$ and radius $r$. S-4 replaces $(a, b, c)$ by $(1,0,2)$, so that she finds $(x-1)^{2}+(y-0)^{2}+(z-2)^{2}=r 2$ as equation (1). The next step, S-4 determines $r$. At the stage, she understands that the radius of the sphere is the distance of the center point with the line $g: x=y=z$. The value of $r=\sqrt{3 x^{2}-6 x+5}$. S-4 substitutes the value of $r$ into equation (1) so that she concludes that the sphere equation should be $2 x^{2}+y^{2}+z^{2}+4 x-4 z=0$.
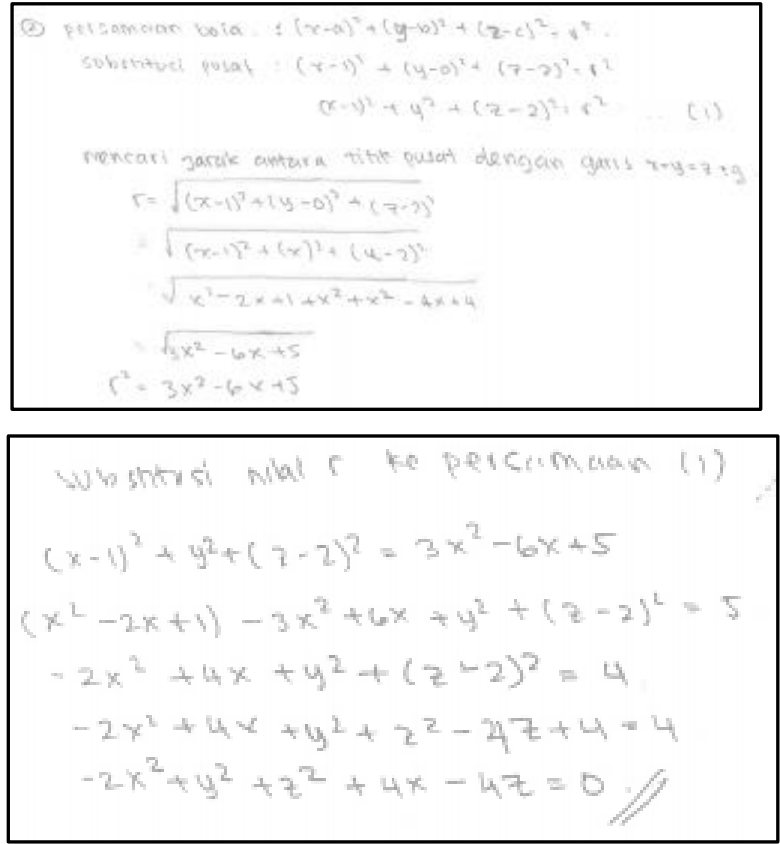

Figure 7 Answer sheet of S-4.

\section{DISCUSSION}

In the aspect of techniques, males and females are able to screen out information and question. However, males prefer to rewrite information while females do not. Another difference that stands out is that males tend to employee an efficient and effective way in solving problems because they have good ability in technical matters and strategies [34]. Moreover, males have a deep understanding of problem patterns and approaches for problem solving. They can see the problems clearly and solve in in the simplest way $[35,36]$. This is caused by several factors, for example cognitive ability and speed in processing information [9]. Females prefer to redraw the sketches to facilitate problem solving, on the one hand. On the other hand, males do not because they have better visual spatial abilities in making visualization in their cognitive [37-39]. This is closely related to the level of testosterone is more dominant in males than those in females [39], and they also have the better right hemisphere [40].

In the aspect of monitoring, males and females showed the same tendency to re-monitor the steps and the conclusion. Re-monitoring conducted to ensure that the steps and answers are correct. The results of monitoring presented by the graffities in their answer sheets. This is a part of the problem-solving process in creating a sense of confidence about their answers [30]. This is relevant to the statement that in solving problems the prospective mathematics teacher checks their steps in ensuring the answers are correct $[41,42]$. Monitoring usually appears in open-ended problems $[43,44]$, but this study shows that the monitoring aspect also appears in non-routine problems. This is because non-routine problems can cause 
confusion to the problem solver and stimulate them to conduct monitoring $[45,46]$.

In the aspect of insight shows that prospective mathematics teachers have the willingness to correct errors answers. Improvements are indicated by the graffities on the answer sheet. A striking difference is that males look enthusiastic and have good self-confidence. This statement is relevant to the results of research that men are more confident in their mathematical abilities [47]. Additionally, the researchers discovered that females often doubt their work and experience more mathematical anxiety. However, females are greater in solving openended problems where processes are more important than correct solutions [38]. This is because females prefer to think of different processes to solve similar problems. In other words, it is easier for males to construct knowledge in their cognitive development than females [48,49] because males have cognitive capacities that are more flexible in the hemisphere [50].

In the aspect of conceptualization, male and female subjects tend not to think of other alternatives to solve problems. They only solve problems by memorizing formulas and steps [51]. This is relevant to the results of research which states that prospective teachers tend to solve problems procedurally without developing alternative solutions [46]. In the indicators relating among concepts, males can relate concepts because they are able to arrange networks or patterns of concepts that have been acquired [50]. Concepts are presented as vertices. The information that connects among concepts establishes a pattern of concept network. If a concept or vertex recalled, the connected vertex or concept will be easier to remember [52]. Recall is the process of remembering the concepts that have been structured in both knowledge and experience [53].

\section{CONCLUSION}

In general, both male and female prospective mathematics teachers bring up all four aspects of reflective thinking. However, males do reflective thinking more leverage than females. The difference lies in the aspects of techniques, insight, and conceptualization. Male prospective mathematics teachers prefer to employee the simplest way to solve problems. Furthermore, they have consistent problem-solving patterns and connected concepts. This is because biological factors, they have a bigger right hemisphere, on the one hand. On the other hand, females' problemsolving patterns tend to fluctuate due to doubt and mathematical anxiety factors.

The difference in reflective thinking between male and female prospective mathematics teachers suspected due to the type of non-routine problem. Researchers recommend further researches employee another question type for instance HOTS problem types, open-ended problems, and application problems. Other research approaches need to be employed such as measuring reflective thinking between both in quantitative design.

\section{AUTHORS' CONTRIBUTIONS}

All authors actively participate in exploring ideas, reviewing literature, collecting the data, analysing the data, and compiling all body articles.

\section{ACKNOWLEDGMENTS}

The authors are very grateful to Director of Directorate of Research and Community Service (DRPM BRIN) the Republic of Indonesia on research funding 2020 on a contract number 10.3.6/UN32.14.1/LT/2020

\section{REFERENCES}

[1]. Batterman RW. On the Explanatory Role of Mathematics in Empirical Science. Br J Philos Sci. 2009;61(1):1-25.

[2]. Weintrop D, Beheshti E, Horn M, Orton K, Jona K, Trouille L, et al. Defining Computational Thinking for Mathematics and Science Classrooms. J Sci Educ Technol. 2016;25(1):127-47.

[3]. Hidajat FA, Sa'dijah C, Sudirman, Susiswo. Exploration of Students 'Arguments to Identify Perplexity from Reflective Process on Mathematical Problems. Int J Instr [Internet]. 2019;12(2):573-86. Available from: https://doi.org/10.29333/iji.2019.12236a

[4]. Markovits H, Barrouillet P. The development of conditional reasoning: A mental model account. Dev Rev [Internet]. 2002;22(1):5-36. Available from: https://doi.org/10.1006/drev.2000.0533

[5]. Holyoak KJ, Morrison RG. The Cambridge Handbook of Thinking and Reasoning [Internet]. The Cambridge handbook of thinking and reasoning. 2005. 874 p. Available from: www.cambridge.org/9780521824170

[6]. Solso RL, MacLin OH, Maclin MK. Cognitive Psychology. UK: Pearson Education Limited; 2014.

[7]. Tisngati U. Proses Berpikir Reflektif Mahasiswa Dalam Pemecahan Masalah Pada Materi Himpunan Ditinjau Dari Gaya Kognitif Berdasarkan Langkah Polya. Beta. 2015;8(2):115-24.

[8]. Gallagher AM, De Lisi R, Holst PC, De Lisi AVM, Morely M, Cahalan C. Gender Differences in Advanced Mathematical Problem Solving. J Exp Child Psychol. 2000;75(3):165-90.

[9]. Zhu Z. Gender Differences in Mathematical Problem Solving Patterns: A Review of Literature. nternational Educ J. 2007;8(2):187-203. 
[10]. Borgonovi F, Greiff S. Societal Level Gender Inequalities Amplify Gender Gaps in Problem Solving More Than in Academic Disciplines. Intelligence. 2020;101422:1-10.

[11]. Dewey J. How We Think: A Restatement of The Relation of Reflective Thinking to The Educative Process. 1st ed. Lexington, Massachusetts, USA: D.C. HEATH AND COMPANY; 1933. 26 p.

[12]. Suharna H, Hairun Y, Abdullah IH, Alhaddad I, Afandi A, Ardiana, et al. The Reflective Thinking Elementary Student in Solving Problems Based on Mathematic Ability. Int J Adv Sci Technol. 2020;29(6):3880-91.

[13]. Agustan S, Juniati D, Siswono TYE. Profile of malefield dependent (FD) prospective teacher's reflective thinking in solving contextual mathematical problem. AIP Conf Proc. 2017;1867(March 2018).

[14]. Gencel IE, Saracaloğlu AS. The Effect of Layered Curriculum on Reflective Thinking and on SelfDirected Learning Readiness of Prospective Teachers. Int $\mathbf{J}$ Progress Educ [Internet]. 2018;14(1):8-20. Available from: http://ijpe.penpublishing.net/makale/410

[15]. Hong YC, Choi I. Three Dimensions of Reflective Thinking in Solving Design Problems: A Conceptual Model. Educ Technol Res Dev. 2011;59(5):687710 .

[16]. Sezer R. Integration of Critical Thinking Skills into Elementary School Teacher Education Courses in Mathematics. Education. 2008;128(3):349-63.

[17]. Susandi AD, Widyawati S. Proses Berpikir dalam Memecahkan Masalah Logika Matematika Ditinjau dari Gaya Kognitif Field Independent dan Field Dependent. 2017;1(1):93-113.

[18]. Tutticci N, Ryan M, Coyer F, Lewis P. Collaborative facilitation of debrief after high-fidelity simulation and its implications for reflective thinking: student experiences. Stud High Educ [Internet]. 2018;43(9):1-14. Available from: https://doi.org/10.1080/03075079.2017.1281238

[19]. Aytekin C, Baltac S, Avni Y. Investigation of Parents ' Expectations from Mathematics Education in Turkey. ACta Didact Napocensia. 2018;11(3):5978.

[20]. Nigrini MJ, Karstens W. Using analytic geometry to quantify the period-to-period changes in an array of values. Manag Audit J. 2019;

[21]. Mojžišová A, Pócsová J. Automatic Test Generator for Analytic Geometry. In: 2019 20th International Carpathian Control Conference (ICCC). Poland: IEEE; 2019.

[22]. Thompson S, Thompson N. The Critically Reflective Practitioner. Macmillan International Higher Education; 2018.
[23]. Schön AD. The Reflective Practioner: How Professionals Think in Action. New York; 1983. 384 p.

[24]. Pagano M. Beyond Reflection Through an Academic Lens: Refraction and International Experiential Education. Interdiscip J Study Abroad Reflect. 2009;18:217-29.

[25]. Foong LYY, Nor MBM, Nolan A. The Influence of Practicum Supervisors' Facilitation Styles on Student Teachers' Reflective Thinking During Collective Reflection. Reflective Pract. 2018;1-18.

[26]. Rodgers C. Defining Reflection:Another look at John Dewey and Reflective thinking. Teach Coll Rec [Internet]. 2002;104(4):842-66. Available from: https://surreyfp.wikispaces.com/file/view/defining+ reflection-Rogers.pdf

[27]. Kholid MN, Sa'dijah C, Hidayanto E, Permadi H. How are students' reflective thinking for problem solving? J Educ Gift Young Sci. 2020;8(3):1135-46.

[28].Edwards-Jones G. Modelling Farmer Decision-making: Concepts, Progress and challenges. Anim Sci. 2006;82(6):783-90.

[29]. Gorghiu G, Gorghiu LM. Applications Solving Geometrical Locus Problems Using Dynamic Interactive Geometry Applications. Res Reflections Innov Integr ICT Educ Solving. 2009;2:814-8.

[30]. Zehavi N, Mann G. Instrumented Techniques and Reflective Thinking in Analytic Geometry. Mont Math Enthus. 2005;2(22):1551-3440.

[31]. Sagala R, Nuangchalerm P, Saregar A, El Islami RAZ. Environment-friendly education as a solution to against global warming: A case study at Sekolah Alam Lampung, Indonesia. J Educ Gift Young Sci. 2019;7(2):85-97.

[32]. Putranta H, Jumadi. Physics Teacher Efforts of Islamic High School in Yogyakarta to Minimize Students' Anxiety When Facing The Assessment of Physics Learning Outcomes. J Educ Gift Young Sci. 2019;7(2):119-36.

[33]. Olsen A, Smolentzov L, Strandvall T. Comparing different eye tracking cues when using theretrospective think aloud method in usability testing. Proc 2010 Br Comput Soc Conf HumanComputer Interact BCS-HCI 2010. 2010;45-53.

[34]. James AN. Gender Differences and the Teaching of Mathematics. Inquiry. 2007;12(1):14-25.

[35]. Pierce S. The Role of Gender and Learning Modality in Mathematical Problem Solving. J Chem Inf Model. 2013;53(9):1689-99.

[36]. Quinn DM, Spencer SJ. The Interference of Stereotype Threat With Women's Generation of Mathematical Problem-Solving Strategies. J Soc Issues. 2002;57(1):55-71. 
[37]. Rimbatmojo S, Kusmayadi TA, Riyadi. Profile of Visual-Spatial Intelligence In Solving Geometric of 11th Grades Viewed From Gender Differences. Int J Sci Appl Sci Conf Ser. 2017;2(1):346-53.

[38]. Geist EA, King M. Different, Not Better: Gender Differences in Mathematics Learning and Achievement. J Instr Psychol. 2008;35(1):43-52.

[39]. Howard PJ. The Owner's Manual for the Brain: Everyday Applications from Mind-Brain Research. Second Edition. Austin: Leornian Press; 2000. 830 p.

[40]. Halpern DF, Benbow CP, Geary DC, Gur RC, Hyde JS, Gernsbacher MA. The Science of Sex Differences in Science and Mathematics. Psychol Sci Public Interes. 2007;8(1):1-51.

[41]. Sa'dijah C, Sa'diyah M, Sisworo, Anwar L. Students' Mathematical Dispositions Towards Solving HOTS Problems Based on FI and FD Cognitive Style. In: AIP Conference Proceedings. 2020. p. 060025-1-060025-7.

[42]. Handayani UF, Sa'Dijah C, Sisworo, Sa'Diyah M, Anwar L. Mathematical creative thinking skill of middle-ability students in solving contextual problems. AIP Conf Proc. 2020;2215(April):060007-1-060007-7.

[43]. Schmitz B, Perels F. Self-monitoring of Selfregulation During Math Homework Behaviour Using Standardized Diaries. Metacognition Learn. 2011;6(3):255-73.

[44]. Titikusumawati E, Sa'dijah C, As'ari AR, Susanto H. The Effectiveness of The Integration of OpenEnded and Collaborative (OE-C) Learning Strategies in Reducing Gaps of Elementary School Students' Creative Thinking Skills. Elem Educ Online. 2013;19(1):198-207.

[45]. Beghetto RA. Lesson Unplanning: Toward Transforming Routine Tasks Into Non-routine Problems. ZDM. 2017;49(7):987-93.

[46]. Lee NH, Yeo DJS, Hong SE. A Metacognitive-based Instruction for Primary Four Students to Approach Non-routine Mathematical Word Problems. ZDM. 2014;46(3):465-80.

[47]. Orhun N. An Investigation into the Mathematics Achievement and Attitude Towards Mathematics with Respect to Learning Style According to Gender. Int J Math Educ Sci Technol. 2007;38(3):321-33.

[48]. Glasersfeld E von. Cognition, Construction of Knowledge, and Teaching. In: Constructivism in Science Education. Springer; 1998. p. 11-30.

[49]. Code L. What can She Know?: Feminist Theory and the Construction of Knowledge. London: Cornell University Press; 1991.
[50]. Miller DI, Halpern DF. The New Science of Cognitive Sex Differences. Trends Cogn Sci. 2014;18(1):37-45.

[51]. Tambychik T, Meerah TSM. Students' Difficulties in Mathematics Problem-solving: What do They Say? Procedia-Social Behav Sci. 2010;8:142-51.

[52]. Stenberg RJ, Stenberg K. Cognitive Psychology. 6th ed. California: Belmont; 2012.

[53]. Krulik S, Milou E, Rudnick J. Teaching Mathematics in Middle School: A Practical Guide. Boston: Pearson Education Inc; 2003. 